\title{
PRE-CRISIS WAGE LEADERSHIP IN CROATIA IN THE CONTEXT OF EXPORT COMPETITIVENESS: ANY LESSONS FOR THE FUTURE?
}

\section{Goran Vukšić*}

\begin{abstract}
This study explores the determinants of sectoral wage dynamics in Croatia, including intersectoral wage linkages, using both panel data methods and Granger causality analysis. Given the large deficits in Croatian merchandise trade and accumulated external liabilities, wage formation in the exporting sectors receives a particular focus. It has been found that exporters are wage leaders and that labour productivity is a more important wage determinant for the exporting sectors than for other sectors. Public sector wages do not affect wages in private sectors. There are, however, wage spillovers within the group of exporting sectors and possibly a bi-directional causal relationship between wages in exporting and private sheltered sectors. Thus, some exporting industries may face pressure from wage increases in more successful exporting sectors as well as in private sheltered sectors. A more coordinated wage-setting system could contribute to improving overall export performance and reducing external trade imbalances.
\end{abstract}

Keywords: wages, wage setting, incomes policy, exports, competitiveness, Croatia JEL Classification: J30, J50, E64, F16

\section{Introduction}

The aim of this study is to investigate the determinants of sectoral wage dynamics in Croatia in the context of improving Croatia's external competitiveness. Developments in Croatian merchandise trade have been characterized by significant deficits: the coverage of merchandise imports by merchandise exports averaged about 48 per cent in the period between 2000 and 2013 (some 43 per cent between 2000 and 2008, and around 56 per cent after the outbreak of the global financial crisis). This strongly contributed to persistent current account deficits amounting to an average of 4 per cent of GDP over the same period (5.5 per cent before 2009, and 1.3 per cent between 2009 and 2013) despite significant tourism income. The narrowing current account deficit in the more recent years was achieved mainly on account of crisis-related consumption and import restraint. Nevertheless,

* Goran Vukšić, Institute of Public Finance, Zagreb, Croatia (goran.vuksic@ijf.hr).

The author is grateful to the Vienna Institute for International Economic Studies (wiiw) and the Global Development Network (GDN) for their financial support. The author would also like to thank all participants of the wiiw-GDN workshop, Vienna, Austria, 2012, as well as the participants of the 28th Annual Congress of the European Economic Association \& 67th European Meeting of the Econometric Society, Gothenburg, Sweden, 2013, for useful comments on earlier versions of the study. While accepting responsibility for remaining errors, the author is grateful to two anonymous referees for valuable comments and suggestions. 
by the end of 2013, the gross external debt of Croatia reached more than 105 per cent of GDP. ${ }^{1}$ Another important aspect is that the competitiveness of Croatian manufacturing exports largely depends on the labour costs of production and is not (particularly) qualitydriven (Stojčić et al., 2012). In the light of these developments and given the country's commitment to a fixed exchange rate policy (due to high euroization), its recent accession to the European Union (EU) and its plans to join the European Monetary Union (EMU) in the future it is necessary to consider policy options other than currency devaluation to improve Croatia's external trade position. If Croatian policy makers are not successful in this respect, the country's recent EU accession may contribute to the widening of the present trade imbalances within the EU. It is thus important to explore whether the current wagesetting process in Croatia can assure that the export competitiveness of Croatian companies is not at risk of wage increases which outpace either their own productivity growth or the relative wage and productivity increases in competitor countries.

There is a large body of literature that addresses the institutional features of incomes policy and wage-setting systems in different countries and their macroeconomic consequences (see Flanagan, 1999, for an overview). These systems are typically distinguished by characteristics such as trade union density, the share of workers covered by the terms of collective bargaining agreements, the level of collective bargaining, and the degree of coordination. The existing research does not provide clear answers as to which wage-setting system type generates the most favourable effects with respect to real wage growth or unemployment (see e.g. OECD, 2004, p. 130) - thus, it seems appropriate to analyse the performance of the overall systems, as different systems may be able to perform equally well.

Bagić (2010) provides a detailed and up-to-date characterization of the Croatian system of wage determination: (1) a comparatively high overall trade union density of about $35 \mathrm{per}$ cent, with large sectoral differences ranging from some 17 per cent in private companies to approximately 70 per cent in the public sector including state-owned enterprises (SOE); (2) at least part of the working conditions for approximately 60 per cent of employees is determined through collective bargaining; ${ }^{2}$ (3) there is no coordination at the industry level; (4) the terms of collective bargaining agreements may be extended by administrative decision; and (5) despite the existence of some sectoral collective agreements, the bargaining process in Croatia is largely decentralized, and, in practice, collective bargaining conducted at the company level in the private sector is more important (Bagić, 2010, pp. 140, 179-182, $187,191,265){ }^{3}$ The last point seems to offer some optimism with respect to the general possibility for Croatian exporters to control their wages and international competitiveness

$1 \quad$ As recognized by the European Commission (EC, 2016), even seven years after the beginning of the crisis, accumulated external liabilities from the pre-crisis period represent a challenge for economic policy in Croatia.

2 However, many of those are covered by private sector collective agreements, which are often not up to date.

3 A similar characterization arises from company survey results for 2013, as presented in Kunovac and Pufnik (2015). 
given the individual companies' positions. However, the wages in the exporting sectors are not isolated from the rest of the economy. They may be affected, through different channels of influence and depending on the labour market situation, by wage increases in other sectors of the economy. While higher wages per se are considered beneficial from the perspective of economic policy aiming at maximizing welfare, if wage increases in non-tradable sectors lead to exporters having to increase wages that in turn endanger their external price competitiveness, external macroeconomic imbalances and sustainability issues may arise, as manifested through large trade deficits and an increasing share of external debt in GDP.

This study attempts to assess the ability of the current Croatian wage-setting process to ensure improvements, or to prevent deterioration, of Croatia's external cost competitiveness, and thus to mitigate macroeconomic (external) imbalances like those which have occurred during the pre-crisis period and which necessitated a difficult and long-lasting adjustment process after the outbreak of the crisis. To achieve this aim, the determinants of sectoral wage developments in Croatia are investigated, including inter-sectoral wage linkages. A good wage-setting system in this context would allow exporters sufficient control over their labour costs and a possibility of adjustment to their productivity dynamics and relevant developments in their exporting markets. This implies that they should not be exposed to (potentially excessive) wage increase pressures from the rest of the economy. It would also allow for a productivity-driven incomes policy that could stabilize the overall wage share and smoothen sustainable domestic demand. The results of this study may have important policy implications. For example, if there are significant inter-sectoral wage spillovers running from non-exporting (private or public) to exporting sectors, these potential upward pressures on exporters' wages might endanger their cost competitiveness and one should therefore consider reforming the wage determination process. An inter-sectoral wage causality running from the government to exporting sectors would imply the explicit possibility of using public sector wages as an instrument for moderating wage increases in the exporting industries. If exporters' wages do not depend on the wage dynamics in the other sectors of the economy, policy-makers can be less concerned about potential pressures on the overall cost competitiveness of the exporters, but there may still be room for improvements in the wage-setting framework if there are heterogeneous developments and inter-sectoral wage linkages within the exporting industry.

The analysis is mostly focussed on the period before the outbreak of the global financial crisis, for two reasons. First, it is exactly this pre-crisis period that is characterized by strong wage increases possibly creating problems for export competitiveness: real gross wages increased by almost 32 per cent in the period between 1998 and 2008. After the breakout of the crisis, real wages declined by around 6 per cent by 2013 . As wages in Croatia cannot be considered flexible (Kunovac and Pufnik, 2015), the consequences of strong wage increases from the pre-crisis period may still be present. Furthermore, as there have been no significant institutional changes in the wage-setting process during later years, lessons from the analysis of the pre-crisis period are of high significance. The second reason is the change in data methodology, i.e. sectoral classification, after 2007, which limits the time dimension of the sample for the panel analysis. Still, a separate section is devoted 
to the discussion of developments after the outbreak of the crisis, which also includes estimating two vector autoregression models for the period between 2000 and 2013 using more recent data classification ${ }^{4}$, in order to analyse the wage leadership hypothesis (i.e. which sectors are leaders in wage formation and affect the other sectors' wages) over the longer period. This section aims to establish whether the results of wage leadership analysis change when the crisis period is also included in the analysis, possibly due to changes in the relative bargaining power of workers and employers during the crisis.

The remaining text is structured as follows: Section 2 gives a brief overview of related literature. Section 3 first describes the sample of data used and the important developments over the observed period. In the second subsection, an econometric analysis is performed using panel data. Subsequently, Granger causality tests of wage leadership are implemented. Section 4 then discusses the developments after the outbreak of the crisis and re-estimates the vector autoregression models over the longer period. The last section discusses the findings and provides concluding remarks and possible policy implications.

\section{Related Literature}

There exists a variety of theoretical models and hypotheses on wage setting, with different predicted outcomes with respect to wage moderation, such as bargaining models, right-tomanage models, the efficiency-wage hypothesis or the insider-outsider hypothesis (see Cahuc and Zylberberg, 2004, for review and references). However, under different theoretical approaches, the outcome of wage-setting in one company or sector may generate negative externalities for other companies or sectors. Some examples include the envy externality or consumer price externality (Calmfors, 1993, pp. 163-164, lists seven types of externalities treated in the literature). Such externalities can be internalized by cooperative wage-setting behaviour through inter-union and inter-employer cooperation. In a largely decentralized system, however, market forces impose restrictions on wages. This leads to the well-known Calmfors - Driffill hypothesis that strongly centralized and decentralized wage-setting systems lead to lower real wages and higher employment than those with an intermediate degree of centralization (Calmfors and Driffill, 1988). ${ }^{5}$ This hypothesis depends on various assumptions and the types of externalities considered (Calmfors, 1993, pp. 167-168), so that one could question the strength of market forces that restrict wages in a decentralized wage bargaining system if, e.g. companies have some market power or if the public sector is considered. In the latter case, fiscal discipline can be a key factor contributing to wage moderation, but under centralized bargaining in the public sector, the government will be negotiating with a large share of the electorate, thus reducing the government's bargaining power.

$4 \quad$ As will be discussed below, after the change in sectoral classification, the Croatian Bureau of Statistics (CBS) recalculated the older data (starting with 2000) on wages and employment according to the new classification. However, this is not the case for data on other variables entering the panel analysis model.

5 Note that strong cooperation can be achieved even without a high degree of formal centralization, e.g. through wage leadership (Knell and Stiglbauer, 2009). 
An important theoretical contribution explicitly addressing inter-sectoral wage linkages in an open economy is known as the Scandinavian model of inflation (Aukrust, 1977). This model distinguishes between exposed and sheltered sectors of an economy with a fixed exchange rate and assumes that wage increases in the exposed sectors are first determined by international prices for the output produced in these sectors and by the productivity of producers in these sectors and are then transmitted to wages in the sheltered sectors. Drawing strongly on Aukrust (1977), D'Adamo (2014) sketches a theoretical framework for the analysis of inter-sectoral wage linkages in an open economy with three sectors: the tradable (exposed) sector and the private and government sheltered sectors. Such a classification allows for a more nuanced discussion of potential wage spillovers from sheltered sectors that may be detrimental to export competitiveness: if wages in the public sector are set without taking into consideration productivity developments in the exposed sectors (e.g. because of public sector unions' high bargaining power) and if there is a tendency toward wage equalization, this may result in cost pressures on the exporting industries. The potential adverse effects of wage leadership from the private sheltered sector characterized by a less competitive environment may become relevant if a country experiences a boom in the private sheltered sector, drawing labour from other sectors and thus placing pressure on exporters.

A number of related empirical studies investigate the relative importance of internal (within a company or a sector) conditions and external factors in determining wages using panel analysis methods with companies or sectors as cross-sectional units. When a macroeconomic wage variable is used to capture external factors, these studies can be interpreted as a test of inter-sectoral wage linkages. For example, using data for the Netherlands, Graafland and Lever (1996) explore the relative importance of internal and external determinants of sectoral wages and find that the latter dominate. They interpret the strong influence of the macro wage on sectoral wages as evidence of the important role of wage leadership patterns. A similar argument is stressed in a study on wage formation within Canadian industry groups by Bemmels and Zaidi (1990). A study by Stockhammer and Onaran (2009) also finds a significant influence of macro wage on wage formation in individual manufacturing industries in the economies of Central and Eastern Europe (CEE). Another group of relevant contributions presents more explicit tests of the wage leadership hypothesis for different sectors in an economy, principally by using time series methods. They often use the Scandinavian model as the primary theoretical reference. For example, in a study on Sweden, Friberg (2007) finds significant inter-sectoral wage causalities, but no indications of the unique wage-leading role of the internationally exposed sector. Interestingly, he finds evidence that the wage causality runs from certain sheltered sectors (other than the public sector) towards the manufacturing sector. Knell and Stiglbauer $(2012,2009)$ find evidence of the wage-leading role of the metal sector in Austria, which is found to be more sensitive to macroeconomic conditions (expectations) than the other sectors. Some related studies focus on potential wage linkages between the public and the private sector in a number of European countries (e.g. Lamo et al., 2012, 2013; Afonso and Gomes, 2014) and specifically in CEE countries (D’Adamo, 2014; and Christou, 2013). 


\section{Empirical Analysis}

\subsection{Sample and relevant developments}

This section uses Croatian data for 50 areas of economic activity according to the NCEA Rev. 1.1, that is, sectors 15-93 (manufacturing and services), in the period between 1998 and 2007. Methodologically consistent data on wages is also available for 2008; such data, however, is not available for other relevant variables. The econometric analysis is performed on the full sample and on groups of sectors separately. The main groups are 'exporting (or exposed) sectors' and 'sheltered sectors'. The latter is then divided into 'private sheltered sectors' and 'government and SOE'. The individual sectors are assigned to groups according to the share of public sector employees and external trade data for that sector. A problem with this approach is that it requires the determination of cut-off points in terms of the public sector employment share or the exporting activities of individual sectors, beyond which a sector will be considered private/public and/or exposed/sheltered. ${ }^{6}$ As there is no objective criterion in this context, different cut-off points can be applied depending on the data and considering the need for a sufficient number of cross-sectional observations in all groups of sectors (for the panel analysis). After examining the data, all manufacturing activities were assigned to exporting sectors, except for '37 Recycling' (which registered no exports) and ' 22 Publishing, printing and reproduction of recorded media' that had an average exportsto-gross-value-added (GVA) ratio of 14.6 per cent (never above 17.5 per cent). The lowest corresponding average ratio in an individual sector assigned to the group of exporting sectors amounted to 45.5 per cent, although, in some years, this ratio amounted to over 70 per cent. The same classification results are achieved using an openness indicator that includes imports as well as exports. In the classification based on the share of public sector employees, the criterion of 50 per cent of employees in an individual sector being employed in publicly-owned entities has been used as a cut-off point between 'private sheltered' and 'government and SOE' groups of sectors (as a robustness check, in some of the later regressions, we apply an alternative criterion of at least $90 \%$ of public employees in order to assign a sector to the group of 'government and SOE').

Figure 1 presents weighted average real gross wages by groups of sectors (deflated using consumer price index with 2005 as the base year). It should be noted that, in the $1994-1999$ period, following the implementation of the stabilization programme in Croatia, real wages increased at rates higher than the real GDP. The crisis in 1999 led to the introduction of changes in wage policy, especially in the public sector, and henceforth,

$6 \quad$ Aukrust (1977, pp.109-110) defines exposed industries as those that are exposed to strong competition from abroad, either because they export most of their products or because they sell their products domestically under strong foreign competition. He states that there is no clear-cut line of division between the two groups, and arbitrary decisions cannot be completely avoided.

7 There is only one exporting sector in which the share of public sector employees exceeds 50 per cent (66 per cent on average but declining to only 15 per cent toward the end of the observed period) and this economic activity is assigned to the group of exporters. Details on the definitions of groups of sectors can be found in Table A1 in the Appendix. 
after 2000, overall real wage increases were held below real GDP growth (Nestić, 2009). Diverging wage developments in the first part of the observed period were primarily due to a strong increase in government and SOE sector wages in the 1998-1999 period. Real wage growth in this group became negative in the 2000-2001 period, which was part of the policies that Croatia implemented in the context of its request for financial support from the IMF at that time. Parallel to these developments, real wages in the private sheltered and exporting sectors began to increase at a higher pace. After 2002, wages in different groups of sectors began moving in a more parallel fashion.

Figure 1 | Real Gross Wages by Groups of Sectors (in 2005 HRK, seasonally adjusted)

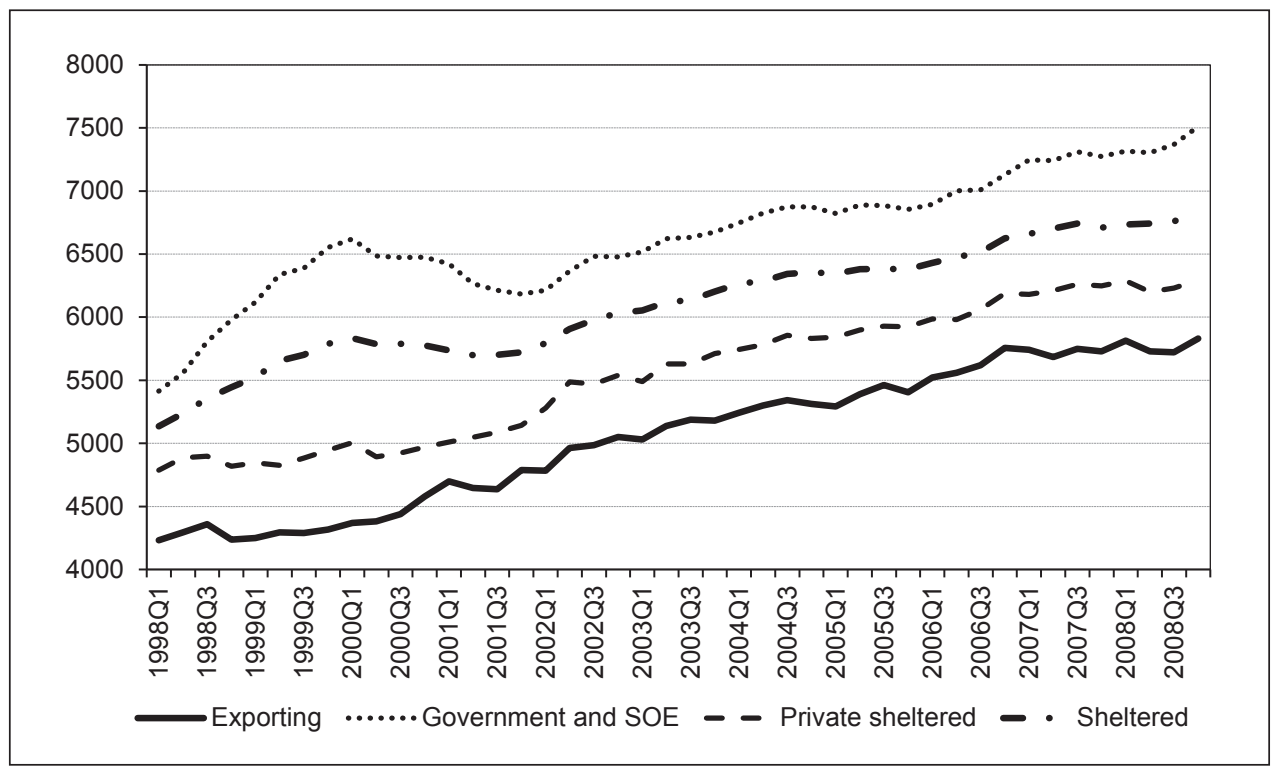

Source: Author's calculations using CBS data.

Table 1 presents per cent changes in some important variables by groups of sectors. Growth in real GVA was the strongest in private sheltered sectors, accompanied by the largest increase in employment. Labour productivity, defined as the ratio of real GVA to employment, increased in the exporting sectors, but employment declined. Since the government and the SOE sectors did not substantially contribute to new employment over the period under study, one can conclude that the output boom among private sheltered sectors may have drawn labour from (some) exporting industries, although wage growth across all groups of sectors was of similar magnitude. ${ }^{8}$ The resulting difference between labour productivity and wage growth was positive for all groups except for the government and SOE sectors.

8 It must be noted that the developments within groups of sectors can be very heterogeneous for individual economic activities. Descriptive statistics for individual exporting sectors shown in Table A2 in the Appendix reveals substantially divergent developments in different industries. 
Table 1 | Growth of Some Relevant Variables by Groups of Sectors (1998-2007, in \%)

\begin{tabular}{|l|c|c|c|c|c|}
\hline & $\begin{array}{c}(\mathbf{1}) \\
\text { Real GVA }\end{array}$ & $\begin{array}{c}\text { (2) } \\
\text { Employment }\end{array}$ & $\begin{array}{c}\text { (3) } \\
\text { Labour } \\
\text { productivity }\end{array}$ & $\begin{array}{c}\text { (4) } \\
\text { Real gross } \\
\text { wages }\end{array}$ & (3) - (4) \\
\hline Exporting sectors & 31.57 & -7.17 & 41.74 & 33.34 & 8.39 \\
\hline Sheltered sectors & 64.87 & 21.37 & 35.84 & 26.29 & 9.55 \\
\hline Private sheltered & 87.54 & 39.59 & 34.35 & 28.10 & 6.25 \\
\hline Government and SOE & 33.05 & 5.34 & 26.30 & 27.34 & -1.04 \\
\hline
\end{tabular}

Source: Author's calculations using CBS data.

\subsection{Panel analysis}

The panel analysis of sectoral wage dynamics and inter-sectoral wage linkages uses annual data for the period between 1998 and 2007. The empirical model specification is taken from related literature and adapted. It is largely empirically motivated meaning that it adds a number of control variables to those implied by the simple underlying theoretical model from Bemmels and Zaidi (1990): they assume the neo-classical market model of labour demand and supply functions in which labour supply depends on the industry wage and on alternative wages, i.e. opportunity cost of labour supply as represented by wages in other industries or sectors. The inclusion of the alternative wages variable is justified on the basis of efficiency wage theories suggesting that it may be profitable for companies to offer wages above the market-clearing level in order to attract better workers, increase their efforts, and minimize their turnover or absenteeism. Labour demand depends on the industrial output and wages. It is also assumed that labour markets do not clear in the same period, which results in the inclusion of the lagged wage growth variable in their empirical specification. Since their dependent variable is nominal wage growth, they also include the expected rate of growth in the price level. Thus, their basic model, with real wage growth as dependent variable, would imply using only the lagged dependent variable, alternative (macroeconomic) wage and labour productivity variable. ${ }^{9}$ The same set of variables (except for the lagged dependent variable) is included in the specification used by Graafland and Lever (1996) who adopt the empirical approach from Nickel and Wadhwani (1990), and which is derived with a reference to the right-to-manage bargaining model. Graafland and Lever (1990) classify the explanatory variables into groups of internal (or sectoral) and external factors in wage formation. The first group consists of labour productivity and the number of union members, while the second group of factors, those that should capture

$9 \quad$ An additional specification used by Bemmels and Zaidi (1990) explicitly adds lagged wage growth in two sectors identified as wage leaders as an explanatory variable. They also test the explicit wage leadership hypothesis using Granger causality analysis (with only wages in leading and other sectors) - an approach taken in numerous empirical studies with reference to the Scandinavian model (Aukrust, 1977) described above, and used in Section 3.3 and Section 4 of the present study as well. 
the outside options of workers, includes the macroeconomic wage rate, the unemployment rate and the average replacement ratio. As already noted, the present study adds a number of control variables to those implied by the simple underlying theoretical model from Bemmels and Zaidi (1990), ${ }^{10}$ as shown in Equation 1 and discussed below:

$$
\begin{aligned}
& \Delta w_{i t}=\alpha+\beta_{1} \Delta w_{i t-1}+\beta_{2} \Delta w_{(-i) t}^{o s}+\beta_{3} \Delta u_{t}+\beta_{4} \Delta e m p l_{i t}+\beta_{5} \Delta l p_{i t}+\beta_{6} \Delta p u b_{i t}+\beta_{7} \Delta e d u_{i t}+ \\
& \beta_{8} \Delta \operatorname{fem}_{i t}+\beta_{9} \Delta a g e_{i t}+\beta_{10} \Delta \exp _{i t}+e_{i t}
\end{aligned}
$$

In the above equation, $i$ denotes individual sectors according to the NCEA Rev. 1.1 (at the level of divisions), and $t$ denotes time. The constant term is denoted by $\alpha$, the $\beta \mathrm{s}$ are the coefficients of the independent variables, while disturbances are denoted by $e_{i t}$. Data is deflated by the consumer price index. The dependent variable is the growth rate of real gross wages by individual sectors $\Delta w_{i t}$, which is also included as an independent variable with a lag: $\Delta w_{i t-1}$. The next two variables should capture the external factors in wage formation: alternative wages and unemployment. The impact of alternative wages is captured by the growth of the weighted average real gross wage in sectors other than $i$ and is denoted by $\Delta w_{(-i) t}^{o s}$ (os stands for other sectors). Depending on the (sub)sample and specification, sectors other than $i$ may refer to (a) all sectors other than $i$ or sectors other than $i$ within a group of sectors, in which case the value of this variable depends on $i$ and is denoted by $\Delta w_{-i t}^{o s}$, or (b) different groups of sectors to which $i$ does not belong (in which case the variable is cross-sectionally invariant and should be denoted in Equation 1 as $\Delta w_{t}^{o s}$ ). Growth in the weighted average real wage in sectors other than $i$ (or in other groups of sectors) instead of macroeconomic wage is used to avoid the potential endogeneity problem that would arise if wage growth in sector $i$ were to significantly affect the growth of the macroeconomic wage (or of the weighted average wage for groups of sectors). The change in the unemployment rate, which should also capture external forces affecting wage formation by representing the labour market conditions (as in Graafland and Lever, 1996) is denoted by $\Delta u_{t}$. No other sector-invariant variables are used, since the short-time dimension of the panel (only eight observations over time, as two are lost due to differencing and lagging) does not allow to reliably differentiate between the effects of more cross-sectionally invariant variables (Graafland and Lever, 1990, face a similar problem but do add the replacement ratio variable in some specifications). ${ }^{11}$

As for the sector-specific variables, sectoral labour productivity growth, denoted by $\Delta l p_{i t}$, is added as implied by the underlying theory and used in empirical specifications of all related studies. Other potentially important explanatory variables include the growth of sectoral employment, $\Delta e m p l_{i t}$, the change in the public employment share in sector $i, \Delta p u b_{i t}$,

10 Stockhammer and Onaran (2009) examine the impact of productivity and macroeconomic wage on sectoral wages, but also add other control variables in additional specifications, without reference to specific derivation from a theoretical model.

11 It should be noted that the real gross wage growth rates of individual sectors are generally not highly correlated with the growth rates of the weighted averages of real wages. Partial exceptions are the wage growth rates of individual sectors in the government and SOE group (see Table A3 in the Appendix). 
and the change in the ratio of exports to GVA in sector $i, \Delta \exp _{i t}$ (in regressions conducted on the full sample and on exporting sectors only). Furthermore, changes in gender composition $\left(\Delta f e m_{i t}\right)$, average age $\left(\Delta a g e_{i t}\right)$, and average educational attainment $\left(\Delta e d u_{i t}\right)$ of sectoral workforce are added since they may affect sectoral wages even in the absence of wage changes at a worker level, due to, e.g. a gender wage gap, different treatment of young or old workers, or because of education wage premium. Table A4 in the Appendix provides an exact description of the variables. The remainder of this section describes the estimation approach and presents the results of the most comprehensive model as laid out in Equation 1. However, at the end of the section, the presented results are briefly compared to results obtained by using a simpler model specification such as the one outlined in Bemmels and Zaidi (1990) and to results of the models in which employment growth is left out.

The model was first estimated for the full sample and different subsamples using a pooled OLS estimator and testing for heteroskedasticity and serial correlation in the error term. The null hypothesis of constant variance was strongly rejected in most cases, and the null hypothesis of no first-order autocorrelation was always rejected. Thereafter, the static version of the model was estimated for different samples using fixed and random effects estimators, which was followed by tests for the significance of individual effects. Both the $\mathrm{F}$ test for fixed effects and the Breusch-Pagan Lagrangian multiplier test for random effects indicated the insignificance of individual effects. This implied that the dynamic model, as presented in Equation 1, can be estimated by using a feasible Generalized Least Square (FGLS) linear panel data estimator robust to heteroskedasticity, and assuming an AR1 process in the errors. For all specifications and samples, the variance inflation factors always showed that multicollinearity does not represent a problem.

The results for the full sample presented in Table 2 suggest that there is no significant evidence of persistence in wage growth. The impact of sectoral labour productivity is always positive and highly significant, though its magnitude is rather small. Sectoral employment growth is negatively related to wage growth, but the corresponding coefficient turns out not to be significantly different from zero. Wages grow faster in sectors with an increasing share of exports, in times of declining unemployment, and with a declining share of public sector and female workers. The latter result may imply that women are more likely to occupy lower-paid jobs, and/or that there exists a significant gender wage gap. The variables capturing the changes in educational attainment levels and the average age of workers are not significant. The growth of the weighted average wage in other sectors is highly significant, with a coefficient of around 0.46 implying much stronger effects from inter-sectoral wage spillovers than from sector-specific productivity growth.

Tables 3 and 4 contain the results for the subsamples of exporting and sheltered sectors, respectively. One notices systematic differences in the results for the two subsamples. Changes in the unemployment rate are mostly insignificant in the subsample of exporters, unlike for the sheltered sectors. Labour productivity and lagged wage growth are highly significant in all the specifications for the group of exporting sectors with considerably higher coefficients than for the full sample or the subsample of sheltered sectors. These differences imply that wage determination in exporting sectors is much less dependent on overall domestic economic 
conditions, i.e. that it is, to a greater extent, determined by sector-specific developments. Such a conclusion is strengthened by the results regarding inter-sectoral wage spillovers: only the wages in exporting sectors other than $i$, as well as in the private sheltered sectors, significantly affect wage growth in individual exporting industries. The corresponding coefficients for the overall sheltered and government and SOE groups of sectors are insignificant. ${ }^{12}$ However, wage growth in all other sectors, in exporting, and in sheltered sectors other than $i$, positively and significantly affects wages in sheltered sectors.

Table 2 | Results of FGLS Panel Estimations for All Sectors

\begin{tabular}{|c|c|c|}
\hline \multirow{2}{*}{ Variables } & \multicolumn{2}{|c|}{ Dependent variable: real gross wages growth $\left(\Delta w_{i t}\right)$} \\
\hline & Other sectors: none & Other sectors: all except $i$ \\
\hline \multirow{2}{*}{$\Delta w_{i t-1}$} & 0.06 & 0.06 \\
\hline & $(0.04)$ & $(0.04)$ \\
\hline \multirow{2}{*}{$\Delta w_{-i t}^{o s}$} & \multirow{2}{*}{ - } & $0.46^{* * *}$ \\
\hline & & $(0.09)$ \\
\hline \multirow{2}{*}{$\Delta u_{t}$} & $-0.35^{* * *}$ & $-0.35^{* * *}$ \\
\hline & $(0.12)$ & $(0.11)$ \\
\hline \multirow{2}{*}{$\Delta e m p l_{i t}$} & -0.04 & -0.04 \\
\hline & $(0.03)$ & $(0.03)$ \\
\hline \multirow{2}{*}{$\Delta l p_{i t}$} & $0.06^{* * *}$ & $0.06^{* * *}$ \\
\hline & $(0.01)$ & $(0.01)$ \\
\hline \multirow{2}{*}{$\Delta p u b_{i t}$} & $-0.05^{* *}$ & $-0.06^{* * *}$ \\
\hline & $(0.02)$ & $(0.02)$ \\
\hline \multirow{2}{*}{$\Delta e d u_{i t}$} & 0.35 & 0.35 \\
\hline & $(0.24)$ & $(0.22)$ \\
\hline \multirow{2}{*}{$\Delta f e m_{i t}$} & $-0.84^{* * *}$ & $-0.86^{* * *}$ \\
\hline & $(0.15)$ & $(0.14)$ \\
\hline \multirow{2}{*}{$\Delta a g e_{i t}$} & -0.09 & -0.01 \\
\hline & $(0.18)$ & (0.18) \\
\hline \multirow{2}{*}{$\Delta \exp _{i t}$} & $0.03^{* * *}$ & $0.03^{* * *}$ \\
\hline & $(0.01)$ & $(0.01)$ \\
\hline \multirow{2}{*}{ constant } & $2.33^{* * *}$ & $1.23 * * *$ \\
\hline & $(0.27)$ & $(0.35)$ \\
\hline Wald $\chi^{2}$ & 80.28 & 119.97 \\
\hline $\begin{array}{l}\text { number of } \\
\text { observations }\end{array}$ & 400 & 400 \\
\hline
\end{tabular}

Notes: ${ }^{* * *},{ }^{* *}$ and ${ }^{*}$ denote significance at 1, 5 and $10 \%$ levels, respectively. Standard errors in ( ). Source: Author's estimations using CBS data.

12 These conclusions also hold when the private sheltered and government and SOE sectors are defined using the $90 \%$ share of public sector employees as a criterion (instead of 50\%). 
Table 3 | Results of FGLS Panel Estimations for Exporting Sectors

\begin{tabular}{|c|c|c|c|c|c|c|}
\hline Variables & \multicolumn{6}{|c|}{ Dependent variable: real gross wages growth $\left(\Delta w_{i t}\right)$} \\
\hline Other sectors: & none & All except $i$ & $\begin{array}{l}\text { Exp. } \\
\text { except } i\end{array}$ & Sheltered & $\begin{array}{l}\text { Private } \\
\text { sheltered }\end{array}$ & $\begin{array}{l}\text { Government } \\
\text { and SOE }\end{array}$ \\
\hline$\Delta w_{i t-1}$ & $\begin{array}{l}0.18^{* * *} \\
(0.06)\end{array}$ & $\begin{array}{l}0.18^{* * *} \\
(0.06)\end{array}$ & $\begin{array}{l}0.17^{* * *} \\
(0.06)\end{array}$ & $\begin{array}{l}0.18^{* * *} \\
(0.06)\end{array}$ & $\begin{array}{l}0.16^{* * *} \\
(0.06)\end{array}$ & $\begin{array}{l}0.18^{* * *} \\
(0.06)\end{array}$ \\
\hline$\Delta w_{(-i) t}^{o s}$ & - & $\begin{array}{c}0.15 \\
(0.16)\end{array}$ & $\begin{array}{l}0.35^{* *} \\
(0.17)\end{array}$ & $\begin{array}{l}0.06 \\
(0.14)\end{array}$ & $\begin{array}{l}0.39 * * * \\
(0.14)\end{array}$ & $\begin{array}{l}-0.05 \\
(0.09)\end{array}$ \\
\hline$\Delta u_{t}$ & $\begin{array}{l}-0.26 \\
(0.19)\end{array}$ & $\begin{array}{l}-0.25 \\
(0.19)\end{array}$ & $\begin{array}{c}-0.40^{* *} \\
(0.20)\end{array}$ & $\begin{array}{l}-0.25 \\
(0.19)\end{array}$ & $\begin{array}{l}-0.11 \\
(0.19)\end{array}$ & $\begin{array}{l}-0.28 \\
(0.19)\end{array}$ \\
\hline$\Delta e m p l_{i t}$ & $\begin{array}{c}0.04 \\
(0.05)\end{array}$ & $\begin{array}{c}0.04 \\
(0.05)\end{array}$ & $\begin{array}{c}0.04 \\
(0.05)\end{array}$ & $\begin{array}{c}0.04 \\
(0.05)\end{array}$ & $\begin{array}{c}0.06 \\
(0.05)\end{array}$ & $\begin{array}{c}0.04 \\
(0.05)\end{array}$ \\
\hline$\Delta l p_{i t}$ & $\begin{array}{l}0.09 * * * \\
(0.02)\end{array}$ & $\begin{array}{l}0.09 * * * \\
(0.02)\end{array}$ & $\begin{array}{l}0.10^{* * * *} \\
(0.02)\end{array}$ & $\begin{array}{l}0.09^{* * *} \\
(0.02)\end{array}$ & $\begin{array}{l}0.09 * * * \\
(0.02)\end{array}$ & $\begin{array}{l}0.10^{* * *} \\
(0.02)\end{array}$ \\
\hline$\Delta p u b_{i t}$ & $\begin{array}{c}-0.08^{* *} \\
(0.04)\end{array}$ & $\begin{array}{c}-0.08^{* *} \\
(0.04)\end{array}$ & $\begin{array}{c}-0.08^{* *} \\
(0.04)\end{array}$ & $\begin{array}{c}-0.08^{* *} \\
(0.04)\end{array}$ & $\begin{array}{c}-0.07^{*} \\
(0.04)\end{array}$ & $\begin{array}{c}-0.08^{* *} \\
(0.04)\end{array}$ \\
\hline$\Delta e d u_{i t}$ & $\begin{array}{l}1.02^{* * *} \\
(0.34)\end{array}$ & $\begin{array}{l}1.01^{* * *} \\
(0.34)\end{array}$ & $\begin{array}{l}0.91^{* * *} \\
(0.34)\end{array}$ & $\begin{array}{l}1.03^{* * *} \\
(0.34)\end{array}$ & $\begin{array}{l}0.96^{* * *} \\
(0.33)\end{array}$ & $\begin{array}{l}1.04^{* * *} \\
(0.34)\end{array}$ \\
\hline$\Delta f e m_{i t}$ & $\begin{array}{c}-1.06^{* * *} \\
(0.20)\end{array}$ & $\begin{array}{c}-1.05^{* * *} \\
(0.19)\end{array}$ & $\begin{array}{l}-1.01^{* * *} \\
(0.20)\end{array}$ & $\begin{array}{c}-1.06^{* * *} \\
(0.20)\end{array}$ & $\begin{array}{c}-0.96^{* * *} \\
(0.19)\end{array}$ & $\begin{array}{c}-1.06^{* * *} \\
(0.20)\end{array}$ \\
\hline$\Delta a g e_{i t}$ & $\begin{array}{c}0.27 \\
(0.23)\end{array}$ & $\begin{array}{c}0.30 \\
(0.23)\end{array}$ & $\begin{array}{c}0.36 \\
(0.23)\end{array}$ & $\begin{array}{c}0.28 \\
(0.23)\end{array}$ & $\begin{array}{l}0.38^{*} \\
(0.23)\end{array}$ & $\begin{array}{c}0.26 \\
(0.23)\end{array}$ \\
\hline$\Delta \exp _{i t}$ & $\begin{array}{l}0.04^{* * *} \\
(0.01)\end{array}$ & $\begin{array}{l}0.04^{* * *} \\
(0.01)\end{array}$ & $\begin{array}{l}0.04^{* * *} \\
(0.01)\end{array}$ & $\begin{array}{l}0.04^{* * *} \\
(0.01)\end{array}$ & $\begin{array}{l}0.04^{* * *} \\
(0.01)\end{array}$ & $\begin{array}{l}0.04^{* * *} \\
(0.01)\end{array}$ \\
\hline constant & $\begin{array}{l}1.20^{* * *} \\
(0.34)\end{array}$ & $\begin{array}{c}0.84 \\
(0.52)\end{array}$ & $\begin{array}{l}-0.06 \\
(0.74)\end{array}$ & $\begin{array}{l}1.07^{* *} \\
(0.43)\end{array}$ & $\begin{array}{c}0.21 \\
(0.49)\end{array}$ & $\begin{array}{l}1.24^{* * *} \\
(0.37)\end{array}$ \\
\hline Wald $\chi^{2}$ & 100.53 & 100.75 & 101.65 & 101.12 & 110.14 & 103.34 \\
\hline $\begin{array}{l}\text { number of } \\
\text { observations }\end{array}$ & 168 & 168 & 168 & 168 & 168 & 168 \\
\hline
\end{tabular}

Notes: ${ }^{* * *}$, $*$ and ${ }^{*}$ denote significance at 1, 5 and $10 \%$ levels, respectively. Standard errors in ( ). Source: Author's estimations using CBS data.

As for the results regarding other variables, the exports variable is again significant, with a positive sign. Educational attainment is always highly significant in the subsample of exporting sectors, and affects the wage growth positively. For the sheltered sectors, coefficients are significant in two specifications, but, unexpectedly, with a negative sign. ${ }^{13}$

13 These results for both subsamples are confirmed with an alternative indicator for educational attainment, defined as the change in the sectoral share of workers with a college degree or higher. In this case, the negative coefficients for the sheltered sectors are significant for three specifications. 
The increase in the share of female workers is negatively related to wage growth in both subsamples with the coefficient being higher (in absolute value) for the exporting sectors. The average age of workers and sectoral employment growth turn out not to be significant for wage growth in the exporting sectors while they are negatively and significantly correlated with wage growth in the sheltered sectors. ${ }^{14}$

Table 4 | Results of FGLS Panel Estimations for Sheltered Sectors

\begin{tabular}{|c|c|c|c|c|}
\hline \multirow{2}{*}{$\begin{array}{c}\text { Variables } \\
\text { Other sectors: }\end{array}$} & \multicolumn{4}{|c|}{ Dependent variable: real gross wages growth $\left(\Delta w_{i t}\right)$} \\
\hline & none & All except $i$ & Exporting & Sheltered except $i$ \\
\hline$\Delta w_{i t-1}$ & $\begin{array}{c}0.01 \\
(0.05)\end{array}$ & $\begin{array}{c}0.00 \\
(0.05)\end{array}$ & $\begin{array}{c}0.04 \\
(0.05)\end{array}$ & $\begin{array}{c}0.00 \\
(0.05)\end{array}$ \\
\hline$\Delta w_{(-i) t}^{o s}$ & - & $\begin{array}{l}0.55^{* * *} \\
(0.13)\end{array}$ & $\begin{array}{l}0.39^{* *} \\
(0.15)\end{array}$ & $\begin{array}{l}0.39 * * * \\
(0.11)\end{array}$ \\
\hline$\Delta u_{t}$ & $\begin{array}{c}-0.33^{* *} \\
(0.17)\end{array}$ & $\begin{array}{c}-0.40^{* *} \\
(0.16)\end{array}$ & $\begin{array}{c}-0.39 * * \\
(0.16)\end{array}$ & $\begin{array}{c}-0.36^{* *} \\
(0.16)\end{array}$ \\
\hline$\Delta e m p l_{i t}$ & $\begin{array}{l}-0.08^{*} \\
(0.04)\end{array}$ & $\begin{array}{l}-0.08^{* *} \\
(0.04)\end{array}$ & $\begin{array}{l}-0.07^{*} \\
(0.04)\end{array}$ & $\begin{array}{c}-0.08^{* *} \\
(0.04)\end{array}$ \\
\hline$\Delta l p_{i t}$ & $\begin{array}{l}0.03^{* *} \\
(0.02)\end{array}$ & $\begin{array}{c}0.03 \\
(0.02)\end{array}$ & $\begin{array}{l}0.03^{*} \\
(0.02)\end{array}$ & $\begin{array}{c}0.03 \\
(0.02)\end{array}$ \\
\hline$\Delta p u b_{i t}$ & $\begin{array}{l}-0.03 \\
(0.03) \\
\end{array}$ & $\begin{array}{l}-0.05^{*} \\
(0.03) \\
\end{array}$ & $\begin{array}{l}-0.04 \\
(0.03) \\
\end{array}$ & $\begin{array}{l}-0.04 \\
(0.03) \\
\end{array}$ \\
\hline$\Delta e d u_{i t}$ & $\begin{array}{l}-0.50^{*} \\
(0.28) \\
\end{array}$ & $\begin{array}{l}-0.32 \\
(0.26) \\
\end{array}$ & $\begin{array}{c}-0.57^{* *} \\
(0.27) \\
\end{array}$ & $\begin{array}{l}-0.33 \\
(0.27) \\
\end{array}$ \\
\hline$\Delta f_{e m}$ & $\begin{array}{c}-0.55^{* *} \\
(0.24)\end{array}$ & $\begin{array}{l}-0.72^{* * *} \\
(0.24)\end{array}$ & $\begin{array}{c}-0.52^{* *} \\
(0.24)\end{array}$ & $\begin{array}{l}-0.70^{* * *} \\
(0.24)\end{array}$ \\
\hline$\Delta a g e_{i t}$ & $\begin{array}{c}-0.83^{* * *} \\
(0.27)\end{array}$ & $\begin{array}{c}-0.58^{* *} \\
(0.27) \\
\end{array}$ & $\begin{array}{c}-0.83^{* * *} \\
(0.27)\end{array}$ & $\begin{array}{c}-0.62^{* *} \\
(0.28) \\
\end{array}$ \\
\hline constant & $\begin{array}{l}3.31^{* * *} \\
(0.38)\end{array}$ & $\begin{array}{l}1.82^{* * *} \\
(0.53)\end{array}$ & $\begin{array}{l}1.85^{* * *} \\
(0.69)\end{array}$ & $\begin{array}{l}2.44^{* * *} \\
(0.45)\end{array}$ \\
\hline Wald $\chi^{2}$ & 35.51 & 55.56 & 43.39 & 50.77 \\
\hline $\begin{array}{l}\text { number of } \\
\text { observations }\end{array}$ & 232 & 232 & 232 & 232 \\
\hline
\end{tabular}

Notes: ${ }^{* *}, * *$ and ${ }^{*}$ denote significance at 1, 5 and $10 \%$ levels, respectively. Standard errors in ( ). Source: Author's estimations using CBS data.

The next two tables, 5 and 6, present separate regression results for the subsamples of private sheltered and government and SOE sectors. Wage developments in individual private sheltered sectors are significantly affected by changes in the unemployment rate,

14 Results for the age variable are confirmed with an alternative indicator defined as the change in sectoral share of workers at 40 years of age or older. 
sectoral employment, share of female workers, changes in average workers' age, and wage developments in all sectors other than $i$, exporting sectors and private sheltered sectors other than $i$. Wage developments in the government and SOE sectors do not have a significant effect on wages in individual private sheltered sectors. ${ }^{15}$ There is no significant persistence in wage growth in private sheltered sectors, and the coefficients of labour productivity growth, public employment, and education are also insignificant.

Table 5 | Results of FGLS Panel Estimations for Private Sheltered Sectors

\begin{tabular}{|c|c|c|c|c|c|}
\hline Variables & \multicolumn{5}{|c|}{ Dependent variable: real gross wages growth $\left(\Delta w_{i t}\right)$} \\
\hline Other sectors: & none & All except $i$ & Exporting & $\begin{array}{c}\text { Private sheltered } \\
\text { except } i\end{array}$ & $\begin{array}{c}\text { Government } \\
\text { and SOE }\end{array}$ \\
\hline$\Delta w_{i t-1}$ & $\begin{array}{l}-0.03 \\
(0.06)\end{array}$ & $\begin{array}{l}-0.05 \\
(0.06)\end{array}$ & $\begin{array}{l}-0.02 \\
(0.06)\end{array}$ & $\begin{array}{l}-0.05 \\
(0.06)\end{array}$ & $\begin{array}{l}-0.04 \\
(0.06)\end{array}$ \\
\hline$\Delta w_{(-i) t}^{o s}$ & - & $\begin{array}{l}0.49 * * * \\
(0.16)\end{array}$ & $\begin{array}{l}0.42^{* *} \\
(0.20)\end{array}$ & $\begin{array}{l}0.51^{* * *} \\
(0.14)\end{array}$ & $\begin{array}{c}0.14 \\
(0.11)\end{array}$ \\
\hline$\Delta u_{t}$ & $\begin{array}{c}-0.43^{* *} \\
(0.21)\end{array}$ & $\begin{array}{c}-0.49^{* *} \\
(0.20)\end{array}$ & $\begin{array}{c}-0.46^{* *} \\
(0.21)\end{array}$ & $\begin{array}{l}-0.18 \\
(0.21)\end{array}$ & $\begin{array}{c}-0.49 * * \\
(0.22)\end{array}$ \\
\hline$\Delta e m p l_{i t}$ & $\begin{array}{c}-0.09 * * \\
(0.05)\end{array}$ & $\begin{array}{c}-0.10^{* *} \\
(0.04)\end{array}$ & $\begin{array}{l}-0.09 * \\
(0.05)\end{array}$ & $\begin{array}{l}-0.07 \\
(0.05)\end{array}$ & $\begin{array}{c}-0.10^{* *} \\
(0.05)\end{array}$ \\
\hline$\Delta l p_{i t}$ & $\begin{array}{c}0.03 \\
(0.02)\end{array}$ & $\begin{array}{c}0.03 \\
(0.02)\end{array}$ & $\begin{array}{c}0.02 \\
(0.02)\end{array}$ & $\begin{array}{c}0.02 \\
(0.02)\end{array}$ & $\begin{array}{c}0.03 \\
(0.02)\end{array}$ \\
\hline$\Delta p u b_{i t}$ & $\begin{array}{l}-0.01 \\
(0.03)\end{array}$ & $\begin{array}{l}-0.02 \\
(0.03)\end{array}$ & $\begin{array}{l}-0.02 \\
(0.03)\end{array}$ & $\begin{array}{l}-0.03 \\
(0.03)\end{array}$ & $\begin{array}{l}-0.01 \\
(0.03)\end{array}$ \\
\hline$\Delta e d u_{i t}$ & $\begin{array}{l}-0.39 \\
(0.35)\end{array}$ & $\begin{array}{l}-0.20 \\
(0.33)\end{array}$ & $\begin{array}{l}-0.54 \\
(0.35)\end{array}$ & $\begin{array}{l}-0.24 \\
(0.33)\end{array}$ & $\begin{array}{l}-0.32 \\
(0.36)\end{array}$ \\
\hline$\Delta f e m_{i t}$ & $\begin{array}{c}-0.59 * * \\
(0.29)\end{array}$ & $\begin{array}{l}-0.81^{* * *} \\
(0.29)\end{array}$ & $\begin{array}{l}-0.56^{*} \\
(0.29)\end{array}$ & $\begin{array}{l}-0.79 * * * \\
(0.29)\end{array}$ & $\begin{array}{c}-0.69 * * \\
(0.30)\end{array}$ \\
\hline$\Delta a g e_{i t}$ & $\begin{array}{c}-0.68^{* *} \\
(0.32)\end{array}$ & $\begin{array}{l}-0.44 \\
(0.33)\end{array}$ & $\begin{array}{c}-0.69 * * \\
(0.32)\end{array}$ & $\begin{array}{c}-0.57^{*} \\
(0.31)\end{array}$ & $\begin{array}{c}-0.56^{*} \\
(0.34)\end{array}$ \\
\hline constant & $\begin{array}{l}3.53^{* * *} \\
(0.48)\end{array}$ & $\begin{array}{l}2.18^{* * *} \\
(0.63)\end{array}$ & $\begin{array}{l}2.00 * * \\
(0.85)\end{array}$ & $\begin{array}{l}1.95^{* * * *} \\
(0.63)\end{array}$ & $\begin{array}{l}3.25^{* * *} \\
(0.52)\end{array}$ \\
\hline Wald $\chi^{2}$ & 24.23 & 36.86 & 28.45 & 39.53 & 25.74 \\
\hline $\begin{array}{l}\text { number of } \\
\text { observations }\end{array}$ & 136 & 136 & 136 & 136 & 136 \\
\hline
\end{tabular}

Notes: ${ }^{* *},{ }^{* *}$ and ${ }^{*}$ denote significance at 1, 5 and $10 \%$ levels, respectively. Standard errors in ( ). Source: Author's estimations using CBS data.

15 These conclusions also hold when the private sheltered and government and SOE sectors are defined using the $90 \%$ share of public sector employees as a criterion (instead of 50\%), except that the results regarding public employment and labour productivity variables from Table 5 are closer to the results obtained for these variables in Table 4. This is not surprising given that the private sheltered sectors sample defined using the $90 \%$ criterion corresponds much more closely to the overall sheltered sectors sample. 
Table 6 | Results of FGLS Panel Estimations for Government and SOE Sectors

\begin{tabular}{|c|c|c|c|c|c|}
\hline \multirow{2}{*}{$\begin{array}{c}\text { Variables } \\
\text { Other sectors: }\end{array}$} & \multicolumn{5}{|c|}{ Dependent variable: real gross wages growth $\left(\Delta w_{i t}\right)$} \\
\hline & none & All except $i$ & Exporting & $\begin{array}{l}\text { Private } \\
\text { sheltered }\end{array}$ & $\begin{array}{l}\text { Government } \\
\text { and SOE } \\
\text { except } i\end{array}$ \\
\hline$\Delta w_{i t-1}$ & $\begin{array}{c}0.13 \\
(0.09) \\
\end{array}$ & $\begin{array}{l}0.18^{* *} \\
(0.09)\end{array}$ & $\begin{array}{c}0.15 \\
(0.09) \\
\end{array}$ & $\begin{array}{l}0.21^{* *} \\
(0.09)\end{array}$ & $\begin{array}{c}0.12 \\
(0.09) \\
\end{array}$ \\
\hline$\Delta w_{(-i) t}^{o s}$ & - & $\begin{array}{l}0.95^{* * *} \\
(0.25)\end{array}$ & $\begin{array}{c}0.18 \\
(0.28)\end{array}$ & $\begin{array}{l}0.73^{* * *} \\
(0.21)\end{array}$ & $\begin{array}{l}0.44^{* * *} \\
(0.14)\end{array}$ \\
\hline$\Delta u_{t}$ & $\begin{array}{l}-0.15 \\
(0.32) \\
\end{array}$ & $\begin{array}{l}-0.28 \\
(0.30) \\
\end{array}$ & $\begin{array}{l}-0.25 \\
(0.33) \\
\end{array}$ & $\begin{array}{l}-0.02 \\
(0.31) \\
\end{array}$ & $\begin{array}{l}-0.17 \\
(0.31) \\
\end{array}$ \\
\hline$\Delta e m p l_{i t}$ & $\begin{array}{l}-0.06 \\
(0.13) \\
\end{array}$ & $\begin{array}{l}-0.05 \\
(0.13) \\
\end{array}$ & $\begin{array}{l}-0.06 \\
(0.13) \\
\end{array}$ & $\begin{array}{l}-0.07 \\
(0.12) \\
\end{array}$ & $\begin{array}{l}-0.06 \\
(0.13) \\
\end{array}$ \\
\hline$\Delta l p_{i t}$ & $\begin{array}{c}0.05 \\
(0.03) \\
\end{array}$ & $\begin{array}{c}0.01 \\
(0.03) \\
\end{array}$ & $\begin{array}{c}0.05 \\
(0.03) \\
\end{array}$ & $\begin{array}{c}0.02 \\
(0.03) \\
\end{array}$ & $\begin{array}{c}0.03 \\
(0.03) \\
\end{array}$ \\
\hline$\Delta p u b_{i t}$ & $\begin{array}{l}-0.19^{* * *} \\
(0.06)\end{array}$ & $\begin{array}{c}-0.20 * * * \\
(0.06) \\
\end{array}$ & $\begin{array}{l}-0.19 * * * \\
(0.06)\end{array}$ & $\begin{array}{l}-0.19 * * * \\
(0.06) \\
\end{array}$ & $\begin{array}{l}-0.20^{* * *} \\
(0.06)\end{array}$ \\
\hline$\Delta e d u_{i t}$ & $\begin{array}{l}-0.60 \\
(0.56) \\
\end{array}$ & $\begin{array}{l}-0.28 \\
(0.51) \\
\end{array}$ & $\begin{array}{l}-0.55 \\
(0.55) \\
\end{array}$ & $\begin{array}{l}-0.29 \\
(0.48) \\
\end{array}$ & $\begin{array}{l}-0.47 \\
(0.54) \\
\end{array}$ \\
\hline$\Delta \mathrm{fem}_{i t}$ & $\begin{array}{l}-0.26 \\
(0.55) \\
\end{array}$ & $\begin{array}{c}0.23 \\
(0.54) \\
\end{array}$ & $\begin{array}{l}-0.26 \\
(0.54) \\
\end{array}$ & $\begin{array}{c}0.15 \\
(0.54) \\
\end{array}$ & $\begin{array}{c}0.00 \\
(0.53)\end{array}$ \\
\hline$\Delta a g e_{i t}$ & $\begin{array}{c}-1.45^{* *} \\
(0.69) \\
\end{array}$ & $\begin{array}{l}-0.75 \\
(0.68) \\
\end{array}$ & $\begin{array}{c}-1.40^{* *} \\
(0.69) \\
\end{array}$ & $\begin{array}{l}-1.18^{*} \\
(0.67) \\
\end{array}$ & $\begin{array}{l}-0.84 \\
(0.69) \\
\end{array}$ \\
\hline constant & $\begin{array}{l}2.85^{* * *} \\
(0.85)\end{array}$ & $\begin{array}{l}-0.37 \\
(1.23)\end{array}$ & $\begin{array}{c}2.12 \\
(1.48)\end{array}$ & $\begin{array}{c}0.31 \\
(1.17)\end{array}$ & $\begin{array}{l}1.60^{*} \\
(0.92)\end{array}$ \\
\hline Wald $\chi^{2}$ & 22.25 & 35.57 & 21.06 & 33.01 & 33.86 \\
\hline $\begin{array}{l}\text { number of } \\
\text { observations }\end{array}$ & 96 & 96 & 96 & 96 & 96 \\
\hline
\end{tabular}

Notes: ${ }^{* *},{ }^{* *}$ and ${ }^{*}$ denote significance at 1,5 and $10 \%$ levels, respectively. Standard errors in ( ).

Source: Author's estimations using CBS data.

Results for the subsample of government and SOE sectors are somewhat different from those for the private sheltered sectors: the coefficient of the lagged wage growth variable is positive and significant in two specifications and the unemployment rate variable is always insignificant, as well as the sectoral employment growth. The share of public employees, on the other hand, turns highly significant, with a much higher (in absolute value) coefficient than in other samples. Interestingly, this is the only subsample in which the gender structure of employees does not turn out to be significant, possibly implying the absence of a gender wage gap. Educational attainment did not affect wage growth, while the increasing average age of employees turns out to be related to lower wage growth rates. Wage growth in sectors other than $i$, private sheltered, and in government and SOE sectors other than $i$ was highly significant, unlike wage developments in the exporting sectors.

If only the lagged dependent variable, labour productivity and alternative wages are included in the model (as in Bemmels and Zaidi, 1990), the results regarding these variables 
are largely confirmed except that: the lagged dependent variable turns significant at the $10 \%$ significance level for the full sample; and, in some specifications, the labour productivity turns significant at $10 \%$ level for private sheltered sectors, and at $5 \%$ level for government and SOE sectors. If only the employment growth variable is excluded from the specifications presented in the above tables, again the lagged dependent variable turns significant at $10 \%$ level for the full sample; significance of labour productivity in the sample of sheltered and private sheltered sectors is slightly increased; and the average workers' age variable turns insignificant for these two subsamples. All the results regarding the inter-sectoral spillovers are confirmed.

\subsection{Granger causality analysis}

As a robustness check for a part of the panel analysis results, the wage leadership of exporting $v s$. sheltered sectors was also investigated using time series methods (as in Bemmels and Zaidi, 1990; Friberg, 2007; Lindquist and Vilhelmsson, 2006; D’Adamo, 2014; or Christou, 2013). This analysis uses quarterly data on average wages between 1998 and 2008. First, an unrestricted bivariate vector autoregressive (VAR) model is specified using the quarterly growth rates of seasonally adjusted data for the weighted average real gross wages in exporting and sheltered industries (denoted by $\Delta w_{t}^{e}$ and $\Delta w_{t}^{s}$, respectively). Subsequently, a system with three equations and variables is analysed: exporting, private sheltered and government and SOE real wage growth (denoted by $\Delta w_{t}^{e}, \Delta w_{t}^{p s}$ and $\Delta w_{t}^{g}$, respectively). In both models, conclusions are derived based on the results of Granger causality/Block exogeneity tests. The VAR model with lag order $p$ and $k$ variables can generally be written as:

$$
\mathbf{W}_{\mathrm{t}}=\boldsymbol{\mu}+\mathbf{A}_{1} \mathbf{W}_{\mathrm{t}-1}+\mathbf{A}_{2} \mathbf{W}_{\mathrm{t}-2}+\ldots+\mathbf{A}_{\mathrm{p}} \mathbf{W}_{\mathrm{t}-\mathrm{p}}+\mathbf{e}_{\mathrm{t}}
$$

where $\mathbf{W}_{\mathrm{t}}$ is a $(\mathrm{k} \times 1)$ vector of variables, $\boldsymbol{\mu}$ is a $(\mathrm{k} \times 1)$ vector of constants, each $\mathbf{A}$ is a $(\mathrm{k} \times \mathrm{k})$ matrix of regression coefficients and $\mathbf{e}_{\mathrm{t}}$ is a $(\mathrm{k} \times 1)$ vector of error terms. In the first VAR model (VAR1), $k=2$ and $\mathbf{W}_{\mathrm{t}}=\left[\Delta w_{t}^{e}, \Delta w_{t}^{s}\right]^{\prime}$. In the second VAR model (VAR2), $k=3$ and $\mathbf{W}_{\mathrm{t}}=\left[\Delta w_{t}^{e}, \Delta w_{t}^{p s}, \Delta w_{t}^{g}\right]^{\prime}$. For both models, the stationarity of the data was tested using the augmented Dickey-Fuller test (ADF). All series are found to be $\mathrm{I}(0)$. Afterwards, the optimal number of lags was selected using different criteria and restricting the maximal number of lags to eight. After estimating the models with six lags, the Jarque - Bera test of the multivariate normality of the residuals (H0: residuals are normally distributed) and the Lagrange multiplier autocorrelation tests of residuals (H0: no serial correlation at lag order $h$ for every $h \leq 8$ ) have been performed. The results of the procedure tests are presented in the notes accompanying Table 7, which summarizes the results of the Granger-causality/ Block exogeneity tests for both models. The results for VAR1 show that one cannot reject the null hypothesis that sheltered sector wage growth does not Granger-cause exporting sector wage growth. The hypothesis of non-causality in the other direction is easily rejected. Regarding the VAR2 model, the hypothesis that wage dynamics in private sheltered or in exporting sectors (considered separately) does not Granger-cause wages in the government sector cannot be rejected. However, the hypothesis that these two sectors' wages do not jointly Granger-cause wages in the government sector is rejected at the $5 \%$ significance level. 
Table 7 | Results of Granger-Causality/Block Exogeneity Tests in VAR Models

\begin{tabular}{|c|c|c|}
\hline \multicolumn{3}{|c|}{ Model VAR1 $(p=6)$} \\
\hline Hypothesis: & $\chi^{2}$ test statistic & p-value \\
\hline$\Delta w_{t}^{e}$ does not Granger-cause $\Delta w_{t}^{s}$ & 20.540 & 0.002 \\
\hline$\Delta w_{t}^{s}$ does not Granger-cause $\Delta w_{t}^{e}$ & 3.407 & 0.756 \\
\hline \multicolumn{3}{|c|}{ Model VAR2 $(p=6)$} \\
\hline Hypothesis: & $\chi^{2}$ test statistic & p-value \\
\hline$\Delta w_{t}^{p s}$ does not Granger-cause $\Delta w_{t}^{g}$ & 3.985 & 0.679 \\
\hline$\Delta w_{t}^{e}$ does not Granger-cause $\Delta w_{t}^{g}$ & 10.084 & 0.121 \\
\hline$\Delta w_{t}^{p s}$ and $\Delta w_{t}^{e}$ do not jointly Granger-cause $\Delta w_{t}^{g}$ & 21.254 & 0.047 \\
\hline$\Delta w_{t}^{g}$ does not Granger-cause $\Delta w_{t}^{p s}$ & 4.732 & 0.579 \\
\hline$\Delta w_{t}^{e}$ does not Granger-cause $\Delta w_{t}^{p s}$ & 14.698 & 0.023 \\
\hline$\Delta w_{t}^{g}$ and $\Delta w_{t}^{e}$ do not jointly Granger-cause $\Delta w_{t}^{p s}$ & 23.335 & 0.025 \\
\hline$\Delta w_{t}^{p s}$ does not Granger-cause $\Delta w_{t}^{e}$ & 7.250 & 0.298 \\
\hline$\Delta w_{t}^{g}$ does not Granger-cause $\Delta w_{t}^{e}$ & 8.618 & 0.196 \\
\hline$\Delta w_{t}^{p s}$ and $\Delta w_{t}^{g}$ do not jointly Granger-cause $\Delta w_{t}^{e}$ & 15.572 & 0.212 \\
\hline
\end{tabular}

Notes: For VAR1: $\mathrm{H}_{0}$ of the JB test cannot be rejected ( $p$-value equals 0.941$)$. The $\mathrm{H}_{0}$ of the LM test cannot be rejected except for $h=6$ (rejected at the 10\% significance level). For VAR2: $\mathrm{H}_{0}$ of the JB test cannot be rejected ( $p$-value equals 0.473 ). The $\mathrm{H}_{0}$ of the LM test cannot be rejected except for $h=5$ (rejected at the $10 \%$ significance level).

Source: Author's estimations using CBS data.

Similarly, the hypothesis that wage developments in exporting sectors, separately and jointly with government sector wages, do not Granger-cause wages in the private sheltered sectors is rejected. Finally, wages in the other two sectors do not affect wages in the exporting sector in the Granger sense.

\section{Developments during the Crisis}

This section considers relevant developments after the outbreak of the crisis. As noted above, the classification of economic activities has changed in 2008, so that the same type of panel analysis as performed in Section 3 cannot be extended to the later period. However, CBS calculated the data on sectoral wages and employment (but not for the other variables used in the panel analysis) according to the new classification (NCEA Rev. 2) for the earlier period starting with 2000 , as well. This provides an opportunity to perform the Granger causality analysis as in Section 3.3, using data that also spans the crisis period, i.e. until 2013, which is the last year for which comparable data is available in the CBS database. The individual manufacturing and services sectors are again grouped into exporting and 
sheltered activities, with the latter being subdivided into private and government and SOE (sheltered) sectors. Despite the efforts to minimize the differences with respect to the earlier aggregation of individual sectors into these broader groups, some differences were unavoidable due to changes in classification. The details are available in the Appendix.

Table 8 | Growth of Real Gross Wages by Groups of Sectors (2000Q1-2013Q4, in \%)

\begin{tabular}{|l|c|c|c|c|}
\hline & 2000Q1-2008Q4 & 2001Q-2008Q4 & 2001Q4-2013Q4 & 2008Q4-2013Q4 \\
\hline Exporting sectors & 29.01 & 20.39 & 12.84 & -6.27 \\
\hline Sheltered sectors & 18.29 & 21.41 & 12.69 & -7.19 \\
\hline Government and SOE & 13.18 & 20.96 & 10.47 & -8.68 \\
\hline Private sheltered & 29.15 & 24.13 & 16.46 & -6.18 \\
\hline
\end{tabular}

Source: Author's calculations using CBS data.

Table 8 shows the real gross wage developments (deflated by CPI, base year 2010) for groups of economic activities based on the new (seasonally adjusted) data, in the period from the first quarter of 2000 to the last quarter of 2013. The growth of real wages in the exporting and private sheltered sectors was quite similar before the crisis, with the growth in government and SOE sectors significantly lagging behind. However, the beginning of the 2000s was marked by wage cuts in the public sector, as explained in Section 3.1 and depicted in Figure 1. If wage developments are compared starting with the last quarter of 2001, in which public sector wages were at the minimum in the period observed, the growth of wages in government and SOE sectors turns out roughly the same as in the exporting activities and smaller than in the private sheltered sectors.

After 2008, real wages in the total economy declined by around 6 per cent by 2013 . At the same time, the unemployment rate, which had been continuously falling between 2000 and 2008, increased during the crisis by about 9 percentage points after 2008, and amounted to around 18 per cent in 2013 (Labour Force Survey data, seasonally adjusted, EC, 2016). Thus, as described by Vukšić (2014), the primary (at aggregate level) mode of adjustment to the crisis was a decline in employment, which exceeded the real wage reductions. The latter was negative in this period in all three groups of economic activities, with the decline being somewhat stronger in government and SOE sectors than in the private sectors, as shown in the last column of Table 8 . The somewhat stronger decline in government and SOE sector wages may possibly be due to a lowered bargaining power of public sector employees during the crisis, because of growing fiscal problems and the need for fiscal consolidation, with general government deficits amounting to $6 \%$ of GDP (2009-2013 average) and public debt rising from around 39\% to $80 \%$ of GDP between the end of 2008 and 2013.

Using the data for the period including the crisis, the VAR1 and VAR2 models described above have been re-estimated. The ADF tests again confirm that all the series are 
$\mathrm{I}(0)$. The analysis was conducted with the same number of lags as in estimations for the precrisis period, i.e. with six lags. ${ }^{16}$ Results are displayed in Table 9.

Table 9 | Results of Granger-Causality/Block Exogeneity Tests in VAR Models (2000-2013)

\begin{tabular}{|c|c|c|}
\hline \multicolumn{3}{|c|}{ Model VAR1 $(p=6)$} \\
\hline Hypothesis: & $\chi^{2}$ test statistic & p-value \\
\hline$\Delta w_{t}^{e}$ does not Granger-cause $\Delta w_{t}^{s}$ & 22.263 & 0.001 \\
\hline$\Delta w_{t}^{s}$ does not Granger-cause $\Delta w_{t}^{e}$ & 17.085 & 0.009 \\
\hline \multicolumn{3}{|c|}{ Model VAR2 $(p=6)$} \\
\hline Hypothesis: & $\chi^{2}$ test statistic & p-value \\
\hline$\Delta w_{t}^{p s}$ does not Granger-cause $\Delta w_{t}^{g}$ & 1.640 & 0.950 \\
\hline$\Delta w_{t}^{e}$ does not Granger-cause $\Delta w_{t}^{g}$ & 4.171 & 0.654 \\
\hline$\Delta w_{t}^{p s}$ and $\Delta w_{t}^{e}$ do not jointly Granger-cause $\Delta w_{t}^{g}$ & 14.313 & 0.281 \\
\hline$\Delta w_{t}^{g}$ does not Granger-cause $\Delta w_{t}^{p s}$ & 10.691 & 0.098 \\
\hline$\Delta w_{t}^{e}$ does not Granger-cause $\Delta w_{t}^{p s}$ & 21.051 & 0.002 \\
\hline$\Delta w_{t}^{g}$ and $\Delta w_{t}^{e}$ do not jointly Granger-cause $\Delta w_{t}^{p s}$ & 36.937 & 0.000 \\
\hline$\Delta w_{t}^{p s}$ does not Granger-cause $\Delta w_{t}^{e}$ & 6.741 & 0.345 \\
\hline$\Delta w_{t}^{g}$ does not Granger-cause $\Delta w_{t}^{e}$ & 5.705 & 0.457 \\
\hline$\Delta w_{t}^{p s}$ and $\Delta w_{t}^{g}$ do not jointly Granger-cause $\Delta w_{t}^{e}$ & 16.587 & 0.166 \\
\hline
\end{tabular}

Notes: For VAR1: $\mathrm{H}_{0}$ of the JB test cannot be rejected ( $p$-value equals 0.905$)$. The $\mathrm{H}_{0}$ of the $L M$ test cannot be rejected. For VAR2: $\mathrm{H}_{0}$ of the JB test cannot be rejected ( $p$-value equals 0.957 ). The $\mathrm{H}_{0}$ of the LM test cannot be rejected.

Source: Author's estimations using CBS data.

For the simpler model, the hypothesis that exporting sector wage growth does not Granger-cause sheltered sector wages is again strongly rejected. However, unlike in the case of the pre-crisis period, the same also holds for the reverse direction of Grangercausality implying a significant impact of sheltered sector wages on those in the exporting sectors. Results for the VAR2 model do not confirm the latter finding from VAR1 model, as the joint hypothesis that private sheltered sector and government sector wage growth does not Granger-cause exporting sector wages cannot be rejected (p-value of 0.166). Results from the richer model also show that only private sheltered sector wages are significantly influenced by wage developments in the other sectors, primarily by those in the exporting

16 The results of the five different lag order selection tests imply five different values for the VAR1 ranging from zero to seven. For the VAR2 model, tests imply an optimal lag order of two (in two cases) or four (three tests). In this case the model with four lags was estimated, but the results of subsequent tests of normality of residuals and serial correlation were unsatisfying. Thus, the VAR2 model was re-estimated with six lags again, as for the pre-crisis period. 
sectors (for which the non-causality hypothesis was rejected at the $1 \%$ significance level). Thus, including the crisis period in the analysis weakens the influence of other sectors' wages on wages in government and SOE sectors, while there is some impact (at the $10 \%$ significance level) of the government sheltered sector on the private sheltered sector wages. That public sector wages did not exert a strong influence on private sector wages during the crisis is found in Kunovac and Pufnik (2015) who present the results obtained in the survey of companies for 2013: $91 \%$ of respondents (private companies) stated that a 3\% public sector wage cut conducted in February 2013 did not have any impact on their wage setting (the share of respondents who responded in this manner amounted to $96 \%$ for a subsample of companies in the manufacturing industry).

\section{Discussion and Conclusions}

This study explores the determinants of sectoral wage dynamics in Croatia, including intersectoral wage linkages. Given the country's large deficits in international trade, which have strongly contributed to the current account deficits and the accumulation of external debt, wage formation in the exporting sectors receives particular focus. The results of the panel estimations for the full sample reveal that external factors, primarily the wage dynamics in other sectors, play a comparatively more important role than sector-specific factors in the wage formation in individual sectors. This is in line with the findings of related research, among others Graafland and Lever (1996), or Stockhammer and Onaran (2009). The results for different subsamples are characterized by a large degree of heterogeneity.

Overall, exporters are wage leaders, and sectoral labour productivity is a comparatively more important wage determinant in the exporting sector than in other sectors. Again, this corresponds to the Scandinavian model (Aukrust, 1977) and empirical findings from D'Adamo (2014) for some CEE countries. The only significant external factors for individual exporting industries are wage developments in other sectors within the exporting group and in private sheltered sectors. The finding that private sheltered sector wages affect the wage growth of exporters is not confirmed by the Granger causality tests for the precrisis period. Given the diverging developments in individual exporting sectors, a potential explanation for the divergent results may be that wages in each sector of the exporting industry (dependent variable) all have equal weights in the panel estimations, while in the time series approach exporters' wage developments are described by the growth in the weighted average of real wages in the exporting sectors. It should, however, be noted that extending the Granger causality analysis to include the crisis period does yield a result that implies a possible bi-directional causality between exporting and the overall sheltered sectors' wages.

Although the exporting sectors are found to be overall wage leaders, the above findings may imply that wage increases in some, more successful exporting industries, and potentially also in private sheltered sectors, do affect wages in other, less successful exporting sectors through some form of externality. As previously noted, there have been heterogeneous developments in individual exporting industries over the observed 
period, and some of the less successful industries experienced positive wage growth at rates exceeding the average of all exporting sectors. Inter-sectoral wage spillovers within the exporting group of sectors may be interpreted as a channel for the restructuring process and viewed as a positive development. If such an interpretation is correct, policy makers might be interested in introducing more control over the intensity of wage pressures. The reason is that the overall export performance and, consequently, the trade balance need not improve if export growth in some sectors does not overcompensate for losses in less successful exporting industries. It seems important, in this context, to recognize the fact that wage (and productivity) growth in the exporting industry went parallel with the decline in employment (even before the crisis), which contributed to significant macroeconomic imbalances and raised external sustainability concerns. That was the period of booming domestic demand reflected in the strong increases of private sheltered sectors' output, largely fueled by capital inflows which helped finance the external deficits. After the outbreak of the crisis and a slowdown of the capital inflows, the economy mostly adjusted through significant employment cuts and consumption and import restraint. The process of adjustment turned out to be very painful and slow, as it takes time to reallocate resources to sectors producing tradable goods (see e.g. IMF, 2012). Moreover, accumulated external liabilities from the pre-crisis period still represent a challenge for economic policy in Croatia seven years after the outbreak of the crisis (as is the low utilization of labour force, i.e. the continuingly high unemployment rates in 2015, see EC, 2016). Therefore, it seems that a wage-setting system that would help to mitigate unsustainable developments in the first place would be useful from the perspective of a policy which aims to avoid large volatility in GDP growth and thus difficult adjustments during prolonged recessions.

One instrument that might be helpful in this respect would be some form of a more coordinated wage-setting system where the wage-increase norm for the overall economy is set in accordance with productivity and price developments in all exporting sectors, as well as taking into account the trade balance developments and unemployment. In the present situation characterized by large accumulated external liabilities, such a system could produce a coordinated wage adjustment which could be helpful in increasing employment and reducing external debt (by enabling larger surpluses in the current account). Above all, it could mitigate wage increases in the future that put wages (and employment) in the exporting sectors under pressure. However, given the institutional features of wage bargaining in Croatia, the question of how to ensure that the norm is obeyed throughout the economy still remains open. In the present institutional setting wage negotiations in the private sector are largely decentralized. Thus, it seems that comprehensive reforms of the wage-setting system in Croatia might be needed. One way forward would be to legally and financially strengthen the role of central institutions in charge of incomes policy (or possibly creating new ones) and to have the employers' associations and the trade unions accept (both medium- and long-term) macroeconomic responsibility rather than fight for vested interests, as well as to strengthen the administrative extensions of (central or industry-level) collective bargaining agreements. 
Final remarks are related to the role of wage developments in the public sector. Government and SOE wages recorded the smallest increase before the crisis and the largest decline during the crisis. Results of the empirical analysis show that they did not significantly affect the private sector wages in the pre-crisis period (neither in the exporting, nor in the private sheltered sectors). Moreover, a higher share of public sector employees is associated with lower real wage growth rates. During the crisis, declines in public sector wages had at best only a small influence on wages in private sheltered sectors. A more coordinated wage-setting system offering a wage-increase norm for the overall economy based on productivity and price developments in the exporting sectors could ensure that there are no excessive pressures from government to private sector wages in the future either.

\section{Appendix}

Table A1 | Definitions of Groups of Sectors

\begin{tabular}{|l|l|}
\hline \multicolumn{2}{|l|}{ Classification for the analysis of the period before the crisis (NCEA Rev. 1.1) } \\
\hline $\begin{array}{l}\text { Exporting } \\
\text { sectors: }\end{array}$ & $\begin{array}{l}\text { Sectors in which the average value of exports over the whole period exceeds } \\
40 \text { per cent of gross value added - all manufacturing sectors except for } 22 \text { and } 37 .\end{array}$ \\
\hline $\begin{array}{l}\text { Sheltered } \\
\text { sectors: }\end{array}$ & All sectors $15-93$ except for exporting sectors. \\
\hline $\begin{array}{l}\text { Private sheltered } \\
\text { sectors: }\end{array}$ & $\begin{array}{l}\text { Sheltered sectors in which average public employment does not exceed } 50 \text { per } \\
\text { cent of total employment - sheltered sectors except for 40-41; 60; 63-64; 73; } \\
75-85 ; 90-92 .\end{array}$ \\
\hline $\begin{array}{l}\text { Government and } \\
\text { SOE: }\end{array}$ & $\begin{array}{l}\text { Sheltered sectors in which average public employment exceeds 50 per cent } \\
\text { of total employment - 40-41; 60; 63-64; 73; 75-85; 90-92. }\end{array}$ \\
\hline Classification for the analysis of the longer period in Section 4 (NCEA Rev. 2) \\
\hline $\begin{array}{l}\text { Exporting } \\
\text { sectors: }\end{array}$ & $\begin{array}{l}\text { The whole manufacturing sector which, according to the NCEA Rev. } 2 \text { now } \\
\text { excludes NCEA Rev. 1.1 activities 37 and (partly: Publishing activities) 22. }\end{array}$ \\
\hline $\begin{array}{l}\text { Sheltered } \\
\text { sectors: }\end{array}$ & All services sectors of the economy. \\
\hline $\begin{array}{l}\text { Private sheltered } \\
\text { sectors: }\end{array}$ & $\begin{array}{l}\text { All services sectors of the economy in which average public employment does } \\
\text { not exceed 50 per cent of total employment - except 49; 52-53; 72; 84-91. }\end{array}$ \\
\hline $\begin{array}{l}\text { Government and } \\
\text { SOE: }\end{array}$ & $\begin{array}{l}\text { All services sectors of the economy in which average public employment } \\
\text { exceeds 50 per cent of total employment - 49; 52-53; 72; 84-91. }\end{array}$ \\
\hline
\end{tabular}

Source: Author's classification using CBS data. 
Table A2 | Descriptive Statistics for the Growth of Variables in Exporting Sectors (1998-2007, in \%)

\begin{tabular}{|l|c|c|c|c|c|c|}
\hline & \multicolumn{5}{|c|}{ Individual sectors } & \multicolumn{2}{c|}{$\begin{array}{c}\text { All exporting } \\
\text { sectors } \\
\text { (total or weighted } \\
\text { average) }\end{array}$} \\
\cline { 2 - 7 } & Average & Median & St. dev. & Max. & Min. & 31.57 \\
\hline (1) Real GVA & 44.94 & 46.45 & 36.18 & 108.50 & -24.05 & 68.32 \\
\hline (2) Real exports & 122.91 & 99.17 & 151.18 & 698.16 & -57.01 & -7.17 \\
\hline $\begin{array}{l}\text { (3) Employment } \\
\text { (4) Labour }\end{array}$ & -4.82 & -6.91 & 28.59 & 62.16 & -49.77 & 41.74 \\
\hline productivity & 59.53 & 50.42 & 51.02 & 243.45 & 3.93 & 33.34 \\
\hline $\begin{array}{l}\text { (5) Real gross } \\
\text { wages }\end{array}$ & 37.04 & 31.38 & 28.38 & 138.27 & 2.65 & 8.39 \\
\hline (6) = (4) - (5) & 22.50 & 12.75 & 56.43 & 221.21 & -49.35 & \\
\hline
\end{tabular}

Source: Author's classification using CBS data.

Table A3 | Simple Correlation Coefficients

\begin{tabular}{|l|c|c|c|c|c|}
\hline \multirow{2}{*}{$\begin{array}{l}\text { Weighted average } \\
\text { real gross wage } \\
\text { growth for: }\end{array}$} & \multicolumn{4}{|c|}{ Real gross wage growth in individual sectors in the (sub)sample of } \\
\cline { 2 - 5 } & All sectors & Exporting & Sheltered & $\begin{array}{c}\text { Private } \\
\text { sheltered }\end{array}$ & $\begin{array}{c}\text { Government } \\
\text { and SOE }\end{array}$ \\
\hline All sectors & 0.04 & -0.13 & 0.15 & 0.01 & 0.51 \\
\hline All except $\boldsymbol{i}$ & 0.00 & -0.12 & 0.08 & -0.03 & 0.36 \\
\hline Exporting & 0.13 & 0.32 & 0.00 & 0.10 & -0.24 \\
\hline Sheltered & 0.01 & -0.16 & 0.13 & -0.02 & 0.49 \\
\hline Private sheltered & 0.14 & 0.20 & 0.11 & 0.14 & 0.03 \\
\hline Government and SOE & -0.04 & -0.22 & 0.09 & -0.07 & 0.47 \\
\hline
\end{tabular}

Source: Author's classification using CBS data. 


\begin{tabular}{|c|c|}
\hline$\Delta w_{i t}$ & $\begin{array}{l}\text { Growth of real gross wages in individual sectors; in \%; consumer price index (CPI) } \\
\text { deflated }\end{array}$ \\
\hline$\Delta w_{(-i) t}^{o s}$ & $\begin{array}{l}\text { Growth of weighted average real gross wages (in period } t \text { ) in all other sectors except } \\
\text { for sector } i \text { (in the whole sample, or in a subsample); by individual sectors; or in other } \\
\text { groups of sectors to which sector } i \text { is not assigned (in this case the variable is cross- } \\
\text { section invariant); in \%; CPI deflated }\end{array}$ \\
\hline$\Delta u_{t}$ & $\begin{array}{l}\text { Change in the unemployment rate (ILO methodology, persons above } 15 \text { years of age); } \\
\text { in percentage points (p.p.) }\end{array}$ \\
\hline$\Delta e m p l_{i t}$ & Growth of total sectoral employment; in \% \\
\hline$\Delta l p_{i t}$ & $\begin{array}{l}\text { Growth of sectoral real labour productivity as defined by real gross value added divided } \\
\text { by the number of employees; in \%; CPI deflated }\end{array}$ \\
\hline$\Delta \exp _{i t}$ & Change in the sectoral ratio of exports and gross value added; in p.p. \\
\hline$\Delta p u b_{i t}$ & $\begin{array}{l}\text { Change in the sectoral share of employees in publicly owned entities in total } \\
\text { employment; in p.p. }\end{array}$ \\
\hline$\Delta e d u_{i t}$ & $\begin{array}{l}\text { Change in sectoral education attainment index constructed considering the minimum } \\
\text { number of years needed to obtain a certain educational level, for } 10 \text { different levels; in \% }\end{array}$ \\
\hline$\Delta f e m_{i t}$ & Change in the sectoral ratio of female and total workers; in p.p. \\
\hline$\Delta a g e_{i t}$ & $\begin{array}{l}\text { Growth of sectoral average age of workers approximated using the weighted average } \\
\text { of the number of workers in different age groups; in \% }\end{array}$ \\
\hline
\end{tabular}

Source: CBS data.

\section{References}

Afonso, A., Gomes, P. (2014). Interactions between Private and Public Sector Wages. Journal of Macroeconomics, 39(A), 97-112, https://doi.org/10.1016/j.jmacro.2013.12.003

Aukrust, O. (1977). Inflation in the Open Economy: A Norwegian Model. Artikler, 96. Oslo: Statistisk Sentralbyra.

Bagić, D. (2010). Ilndustrijski odnosi u Hrvatskoj: Društvena integracija ili tržišni sukob. (Industrial Relations in Croatia - Social Integration or Social Conflict) Zagreb: TIM press. ISBN 978-953-7177-43-0.

Bemmels, B. G., Zaidi, M. A. (1990). Wage Leadership in Canadian Industry. Applied Economics, 22(4), 553-567, https://doi.org/10.1080/00036849000000011

Cahuc, P., Zylberberg, A. (2004). Labor Economics. Cambridge, Massachusetts: MIT Press. ISBN 9780262033169.

Calmfors, L., Driffill, J. (1988). Bargaining Structure, Corporatism, and Macroeconomic Performance. Economic Policy, 3(6), 13-61, https://doi.org/10.2307/1344503

Calmfors, L. (1993). Centralisation of Wage Bargaining and Macroeconomic PerformanceA Survey. OECD. Economic Studies No. 21, https://doi.org/10.1787/521405217277

Christou, C. (2013). The Dynamics of Wage Determination in Romania. Economics of Transition, 21(4), 713-729, https://doi.org/10.1111/ecot.12026

D’Adamo, G. (2014). Wage Spillovers across Sectors in Eastern Europe. Empirical Economics, 47(2), 523-552, https://doi.org/10.1007/s00181-013-0744-z 
EC (2016). Country Report Croatia 2016. Including an In-Depth Review on the Prevention and Correction of Macroeconomic Imbalances. Brussels: European Commission.

Available at: http://ec.europa.eu/europe2020/pdf/csr2016/cr2016_croatia_en.pdf

Flanagan, R. J. (1999). Macroeconomic Performance and Collective Bargaining: An International Perspective. Journal of Economic Literature, 37(3), 1150-1175, https://doi.org/10.1257/ jel.37.3.1150

Friberg, K. (2007). Intersectoral Wage Linkages: the Case of Sweden. Empirical Economics, 32(1), 161-184, https://doi.org/10.1007/s00181-006-0077-2

Graafland, J. J., Lever, M. H. C. (1996). Internal and External Forces in Sectoral Wage Formation: Evidence from the Netherlands. Oxford Bulletin of Economics and Statistics, 58(2), 241-252, https://doi.org/10.1111/j.1468-0084.1996.mp58002002.x

IMF (2012). Internal Devaluation - The IMF View.

Available at: https://kkalev4economy.wordpress.com/2012/03/20/ internal-devaluation-the-imf-view/

Lamo, A., Pérez, J. J., Schuknecht, L. (2012). Public or Private Sector Wage Leadership? An International Perspective. Scandinavian Journal of Economics, 114(1), 228-244, https://doi.org/ 10.1111/j.1467-9442.2011.01665.x

Lamo, A., Pérez, J. J., Schuknecht, L. (2013). Are Government Wages Interlinked with Private Sector Wages? Journal of Policy Modeling, 35(5), 697-712, https://doi.org/10.1016/j. jpolmod.2012.12.003

Lindquist, M. J., Vilhelmsson, R. (2006). Is the Swedish Central Government a Wage Leader? Applied Economics, 38(14), 1617-1625, https://doi.org/10.1080/00036840500407124

Knell, M., Stiglbauer, A. (2012). The Impact of Reference Norms on Inflation Persistence when Wages Are Staggered. International Economic Review, 53(2), 569-592, https://doi.org/10.1111/j.1468-2354.2012.00692.x

Knell, M., Stiglbauer, A. (2009). Wage Staggering and Wage Leadership in Austria - Review and Implications. Oesterreichische Nationalbank. Monetary Policy \& the Economy, q4/09, 79-97.

Kunovac, M., Pufnik, A. (2015). Features of the Labour Market and Wage Setting in Croatia: Firms Survey Results. Surveys S-19. Zagreb: Croatian National Bank.

Nestić, D. (2009). Plaće u Hrvatskoj: trendovi, problemi i očekivanja, in Franičević. (Wages in Croatia:Trends, Pending Issues and Expectations, in Franičević), V., Puljiz, V., eds., Labour in Croatia: Facing challenges of future. Zagreb: Centar za demokraciju i pravo Miko Tripalo; Pravni fakultet Sveučilišta u Zagrebu, pp. 165-195.

Nickell, S., Wadhwani, S. (1990). Insider Forces and Wage Determination. The Economic Journal, 100(401), 496-509, https://doi.org/10.2307/2234136

OECD (2004). Employment Outlook. Paris: Organization for Economic Cooperation and Development.

Stockhammer, E., Onaran, O. (2009). National and Sectoral Factors in Wage Formation in Central and Eastern Europe. European Journal of Industrial Relations, 15(3), 317-338, https://doi.org/ 10.1177/0959680109339417

Stojčić, N., Bečić, M., Vojinić, P. (2012). The Competitiveness of Exports from Manufacturing Industries in Croatia and Slovenia to the EU-15 Market: A Dynamic Panel Analysis. Croatian Economic Survey, 14(1), 69-105.

Vukšić, G. (2014). Employment and Employment Conditions in the Current Economic Crisis in Croatia. Financial Theory and Practice, 38(2), 103-138, https://doi.org/10.3326/fintp.38.2.1 